IZA DP No. 8741

Sexual Orientation Discrimination in the United Kingdom's Labour Market:

A Field Experiment

Nick Drydakis

December 2014 


\title{
Sexual Orientation Discrimination in the United Kingdom's Labour Market: A Field Experiment
}

\author{
Nick Drydakis \\ Anglia Ruskin University \\ and IZA
}

Discussion Paper No. 8741

December 2014

\author{
IZA \\ P.O. Box 7240 \\ 53072 Bonn \\ Germany \\ Phone: +49-228-3894-0 \\ Fax: +49-228-3894-180 \\ E-mail: iza@iza.org
}

Any opinions expressed here are those of the author(s) and not those of IZA. Research published in this series may include views on policy, but the institute itself takes no institutional policy positions. The IZA research network is committed to the IZA Guiding Principles of Research Integrity.

The Institute for the Study of Labor (IZA) in Bonn is a local and virtual international research center and a place of communication between science, politics and business. IZA is an independent nonprofit organization supported by Deutsche Post Foundation. The center is associated with the University of Bonn and offers a stimulating research environment through its international network, workshops and conferences, data service, project support, research visits and doctoral program. IZA engages in (i) original and internationally competitive research in all fields of labor economics, (ii) development of policy concepts, and (iii) dissemination of research results and concepts to the interested public.

IZA Discussion Papers often represent preliminary work and are circulated to encourage discussion. Citation of such a paper should account for its provisional character. A revised version may be available directly from the author. 


\section{ABSTRACT}

\section{Sexual Orientation Discrimination in the United Kingdom's Labour Market: A Field Experiment}

Deviations from heteronormativity affect labour market dynamics. Hierarchies of sexual orientation can result in job dismissals, wage discrimination, and the failure to promote gay and lesbian individuals to top ranks. In this paper, I report on a field experiment (144 jobseekers and their correspondence with 5,549 firms) that tested the extent to which sexual orientation affects the labour market outcomes of gay and lesbian job-seekers in the United Kingdom. Their minority sexual orientations, as indicated by job-seekers' participation in gay and lesbian university student unions, negatively affected their workplace prospects. The probability of gay (lesbian) applicants receiving an invitation for an interview was $5.0 \%$ (5.1\%) lower than that for heterosexual male (female) applicants. In addition, gays (lesbians) received invitations for interviews by firms that paid salaries that were $1.9 \%(1.2 \%)$ lower than those paid by firms that invited heterosexual male (female) applicants for interviews. In addition, in male- (female-) dominated occupations, gay men (lesbians) received fewer invitations for interviews than their non-gay (non-lesbian) counterparts. Furthermore, gay men (lesbians) also received fewer invitations to interview for positions in which masculine (feminine) personality traits were highlighted in job applications and at firms that did not provide written equal opportunity standards, suggesting that the level of discrimination depends partly on the personality traits that employers seek and on organisation-level hiring policies. I conclude that heteronormative discourse continues to reproduce and negatively affect the labour market prospects of gay men and lesbians.

JEL Classification: $\quad \mathrm{C} 93, \mathrm{~J} 7, \mathrm{~J} 82$

Keywords: field experiment, heteronormativity, interviews, selection, sexual orientation, wage offers

Corresponding author:

Nick Drydakis

Lord Ashcroft International Business School

Anglia Ruskin University

East Road

Cambridge, BB1 1PT

United Kingdom

E-mail: nick.drydakis@anglia.ac.uk 


\section{Introduction}

Despite recent legal changes that have improved the lives of gays and lesbians, sexual orientation minorities continue to experience the effects of social inequality (Ozeren, 2014). Sexual orientation minorities have reported that they are bullied and made to feel frightened and that they suffer from low selfesteem (Ellison and Gustone, 2009; Hunt and Jensen, 2007). Simultaneously, because of the limited research conducted regarding employing gay men and lesbians, the potential disadvantages that sexual orientation minorities experience may have gone unnoticed and remained unchallenged by researchers, activists and social planners. However, demand for research on sexual orientation has grown over the years owing to requirements related to labour legislation and the need for policy evaluation (European Union Agency for Fundamental Rights, 2009).

Studies suggest that the hiring process is perhaps the single most important but least understood part of the employment relationship (Petersen et al., 2000; Pager and Karafin, 2009). People who face biased treatment in the hiring process must spend more time and resources finding jobs, and firms lose potential talent as a result of biased hiring (Equality Challenge Unit, 2009). The lack of direct evidence regarding a hiring bias against openly gay men and lesbians limits our knowledge regarding the extent of the discrimination that sexual orientation minorities may face in the initial stage of the hiring process (Tilcsik, 2011).

In this paper, I present the outcomes of a field experiment related to sexual orientation in the United Kingdom by examining labour bias against gay and lesbian first-time job-seekers. University students commonly participate in student unions and frequently describe in their curriculum vitae (CV) their volunteer experiences while at university because these are perceived as pre-professional experiences (National Unions of Students, 2009). Student unions aim to lobby, campaign, debate, and undertake representative activities. For example, student unions representing women, ethnic minorities, and students with physical disabilities aim to address societal inequalities and are important organisations for championing and campaigning for human rights (National Unions of Students, 2009). For gay and lesbian students in particular, institutions of higher education have traditionally been viewed as accepting spaces (Equality Challenge Unit, 2009); however, there is limited information available as to whether gay and lesbian students as first-time job-seekers face discrimination when applying for jobs.

In the research literature, Adam (1981) was the first to examine hiring discrimination against gay men and lesbians in Toronto, Canada. After sending out identical CVs to firms for males and females, except that half of the CV's included 'Active in Gay People's Alliance' as a line item, the study revealed a 10\% reduction in job interview offer rates for gay and lesbian applicants. Adam explicitly used the word 'gay' to label applicants' sexual orientations, which enabled a measure for the biased treatment of nonheteronormative people. Weichselbaumer (2003) employed a similar technique to investigate whether the Austrian labour market discriminated against lesbian applicants; she found that representation of a lesbian identity through participation in the local 'Gay and Lesbian Alliance' reduced the interview offer rate by 12 $13 \%$. 
Similarly, Drydakis (2009; 2011) observed that gay men (lesbians) who represented that they had volunteer engagements in gay and lesbian organisations received fewer invitations for interviews by $26 \%$ (27\%) and lower initial wage offers by 1.5\% (6\%) from employers in Greece. Furthermore, Tilcsik (2011) estimated that gay men who had experience in a gay campus organisation in the United States were $40 \%$ less likely to receive a job interview than were their heterosexual counterparts. The same study also found that employers who emphasised the importance of stereotypically masculine traits in their job advertisements were particularly likely to discriminate against gay men. Finally, Ahmed et al. (2013) found that gay men who were engaged in the 'Swedish Federation for Lesbian, Gay, Bisexual and Transgender Rights' received fewer invitations for interviews by 3-6\%, and lesbians received fewer invitations for interviews at a rate of $6 \%$. The results of that study also revealed that discrimination against gay men was higher with respect to male-dominated jobs, whereas discrimination against lesbians was more pronounced in female-dominated occupations.

In the present study, I consider all of these aspects of sexual orientation discrimination against both gay and lesbian students by conducting a comprehensive field experiment in the United Kingdom, which is a country that has been understudied in this regard. As opposed to the previous field experiments (Adam, 1981; Weichselbaumer, 2003; Drydakis, 2009; 2011; Tilcsik, 2011; Ahmed et al., 2013), the current study contributes to the literature by applying a post-structuralist theoretical framework (Foucault, 1980; 2001; Ozturk, 2011; Prasad, 2012) to sexual orientation to set up hypotheses and test labour market biases against gay men and lesbians.

My purpose in this study is to use a comprehensive theoretical framework of the unequal ordering of sexualities with the aim of providing solid empirical evidence for gay and lesbian university students, which is an invisible theme in the academic and political discourse. In addition, by using workplaces as sexualised environments, I aim to evaluate empirically whether occupation characteristics affect sexual minorities' workplace prospects. In the current study, by capturing potentially biased treatments in the event of discrimination, I will evaluate whether compulsory heterosexuality at the institutional level is sustained and I will attempt to gain an in-depth understanding of daily workplace practices. A main advantage of this approach is that I will evaluate the in vivo experiences of gay and lesbian individuals in the labour market.

The hypotheses and research design of this study enable me to answer the following questions: (1) Do gay men and lesbians receive fewer invitations for interviews and lower entry-level annual salaries than heterosexuals? (2) Do male-/female-dominated occupations affect the chances that gay men and lesbians will receive an invitation to interview and the amount of their entry-level annual salaries? (3) Can job openings' ideal advertised masculine/feminine personality traits for applicants affect the rate at which gay men and lesbians receive invitations for interviews and their entry-level annual salaries? (4) Can the absence of written commitments to equal employment opportunity affect gay and lesbian applicants' invitations for interviews and their entry-level annual salaries?

The current study provides a credible way to reveal discrimination in hiring and provide good data for policy makers. Social planners should be interested in knowing whether heteronormative discourses and 
gender assumptions continue to be prevalent in the United Kingdom, even after the favourable legal climate that has developed since the introduction of the anti-discrimination labour legislation in 2010.

\section{Conceptual Framework}

The theoretical approach that the current study adopts is consistent with the work of other authors who have examined sexual orientation in the workplace (Willis, 2012; Ozturk, 2011; Rumens and Kerfoot, 2009; Prasad, 2012; Rumens, 2010; 2012). Based on concepts grounded in post-structuralism, there is an unequal ordering of sexualities (Foucault, 1980; 2001). Sexual orientation majorities and minorities are embedded in complex networks of social relations. These relations, in turn, determine which subjects can appear where and in what capacities (Foucault, 1990; 2001). Homosexual experiences are perceived as either shameful or potentially deviant, whereas heterosexual experiences are valued and viewed as the 'right' way to live (Yep, 2002). As with victims of sexism and racism, dominant social groups identify sexual orientation minorities as somehow less than fully human and not entitled to the same rights as 'normal' people (Donnelly, 1999; Ozturk, 2011). These groups understand homosexuality as representing a lower order of existence of 'others', with fairness skewed in favour of heterosexuals and homosexuality serving to sustain the superiority of heterosexuality (Foucault, 2001; Butler, 2004; Prasad, 2012).

When homosexual individuals are treated as inferiors, they highlight homosexuals' perceived weaknesses to make themselves look stronger or better. Such categorisation implies hierarchy and serves to maintain existing power relations (Butler, 2004). Statistics reveal a number of patterns that appear to highlight the unequal ordering of sexual orientations (Equality Challenge Unit, 2009). Gay men and lesbians most commonly reveal problems relating to a sense of inferiority, openly homophobic verbal and physical abuse, having to keep their sexual orientation a secret and live with less freedom than they would desire, problems with their families, school and universities, and problems with their neighbourhoods, colleagues and social services (Equality Challenge Unit, 2009).

In particular, the sociological and organisational literature views workplaces as sexualised environments (Fleming, 2007; Ozturk, 2011). Heterosexual employees are privileged by their normalised status within organisations (Bruni, 2006; Hird, 2004; Pringle, 2008; Broadbribge and Hean, 2008), and the dominant discourse of heterosexuality in organisations tends to silence the dominated discourse of homosexuality, the latter of which is credited with at most limited legitimacy and protection (Pringle, 2008). Through the othering process, organisations apportion higher status to heterosexuality, which reinforces power hierarchies and ostracises constituents who belong to other sexual categories (Foucault, 1990; 2001; Gusmano, 2008).

Heteronormativity creates, nurtures, maintains and perpetuates daily acts of violence and bias against employees and groups who are outside of the domain of natural sexuality (Butler, 1990; Hird, 2004; Pringle, 2008). The heteronormative discourse acts as a mechanism of control that limits the ability of sexual orientation minority employees to discuss and construct their own identities (Hird, 2004; Pringle, 2008; Broadbribge and Hean, 2008). Indeed, gay men and lesbians report reluctance to disclose their sexual 
orientation in the workplace for fear of biased treatment, and sexual orientation minorities are vulnerable to high levels of stress-related illness (Equality and Human Rights Commission, 2009).

Studies suggest that sexual orientation minorities are affected by professional norms and a heteronormativity discourse that treats sexual orientation and professionalism as polar opposites (Rumens and Kerfoot, 2008; Willis, 2012). For example, studies find that sexual orientation affects decisions about employment routes prior to applying for particular jobs, particularly in sectors such as law enforcement and the armed forces, teaching and manual trades (Ellison and Gustone, 2009). These professions implicitly reinforce the interests of heterosexuals (Rumens and Kerfoot, 2008). Sexual minorities have found themselves under pressure to keep their sexuality out of these professions for fear of being misread as sexually ‘dangerous' subjects (Foster and Newman, 2005).

Deviations from heteronormativity are frequently found to be the basis for workplace discrimination (Ward and Winstanley, 2003). Theoretical studies conclude that sexual orientation discrimination expresses the heterosexual nature of the workplace (Ragins et al., 2003; Martinsson et al., 2007). Reports find that gay men and lesbians are more than twice as likely as other employees to report bullying or harassment and nearly twice as likely to report experiencing unfair treatment (Employment Market Analysis and Research, 2009; Badgett et al., 2007). In addition, there is evidence that gay men are overlooked for promotion to topranking positions and in some cases are not provided with domestic partner insurance (Ozeren, 2014; Badgett et al., 2007; Frank, 2006; Arabsheibani et al., 2005; Equality Challenge Unit; 2009). Furthermore, in a number of international studies that controlled for education, working experience, and occupations, gay and lesbian employees received lower earnings than did their heterosexual counterparts (Carpenter, 2008; Drydakis, 2014). The hierarchy of sexualities appears to affect wages and maintain existing power relations (Butler, 2004). Finally, homosexual-oriented jokes reinforce power inequalities and characterise sexual orientation minority employees as the sexual Other (Ward and Winstanley, 2003).

In the present study, I designed a correspondence test similar to that of Weichselbaumer (2003) and Tilcsik (2011) to measure direct incidents of biased treatment towards sexual orientation minorities. The aim of this field study is to test whether deviations from heteronormativity that are signalled through job-seekers' participation in gay and lesbian student unions at university are penalised in the labour market. More specifically, I want to test whether applicants' sexual orientations affect their invitations for interview and their entry-level annual salaries. The rationale for the study's hypotheses derives from the theoretical framework of this study and the disadvantaged position of gay men and lesbians in the workplace that the international empirical literature has captured. The two main hypotheses related to sexual orientation and workplace outcomes are the following:

Hypothesis 1.a: Gay men (lesbians) are likely to receive fewer invitations for interviews than heterosexual men (women) receive.

Hypothesis 1.b: Gay men (lesbians) are likely to receive lower entry-level annual salaries than heterosexual men (women) receive.

A number of relationships within the workplace environment may influence gay and lesbian invitations for interviews and their entry-level salaries. The design of this study enables me to estimate 
whether male- or female-dominated occupations, masculine and feminine personality traits and/or workplace characteristics affect workplace outcomes.

Ideology and the discourse of gender play significant roles in promoting and sustaining the sexual division of labour, the social definition of tasks as either men's work or women's work, and the penalties for those who upset gender assumptions (Morgan, 1992; Williams, 1993). Owing to heteronormative standards, gay men may face higher disadvantages in male-dominated occupations because of their minority status through negative stereotyping (Connell, 2000; Collins, 2013; Chung and Harmon, 1994), and empirical studies support this argument (Ahmed, et al., 2013). Similarly, lesbians might face greater disadvantages in female-dominated occupations because they deviate from the normative standard and its expectations (Hook and Bowman, 2008; Ahmed, et al., 2013). The second set of hypotheses, which are related to sexual orientation, male-/female-dominated occupations and workplace outcomes, consist of the following:

Hypothesis 2.a: Gay men are likely to receive fewer invitations for interviews with respect to maledominated occupations than are heterosexual men.

Hypothesis 2.b: Lesbians are likely to receive fewer invitations for interviews with respect to femaledominated occupations than are heterosexual women.

Hypothesis 2.c: Gay men are likely to receive lower entry-level annual salaries in male-dominated occupations than are heterosexual men.

Hypothesis 2.d: Lesbians are likely to receive lower entry-level annual salaries in female-dominated occupations than are heterosexual women.

In addition, studies have emphasised that a critical factor in determining who is hired for a job is the degree of congruence between the gender and personality traits of the applicant and the sex type, attributes, and characteristics of the advertised vacancy (Weichelbaumer, 2003; 2004; Tilcsik, 2011). Societies typically assign a highly specific set of meanings to gender. Based on heteronormative norms, men are masculine and women feminine (Yep, 2002). The heteronormative dominant group typically characterises sexual orientation minorities who deviate or are perceived to deviate from the norm as having something wrong with them (Yep, 2002; Martinsson et al., 2007).

Studies suggest that gay men are treated with particular disgust for transgressing hyper-masculine gender role expectations (Embrick et al., 2007). Based on this framework, it might be suggested that firms that seek employees with stereotypically masculine traits should be more likely to discriminate against gay men if they value attributes that gay men are stereotypically perceived to lack (Tilcsik, 2011, Connell, 2005; Madon, 1997). In addition, it might be suggested that firms that seek employees with stereotypically feminine traits should be more likely to have biased attitudes towards lesbians if they prefer personality characteristics that lesbians are stereotypically assumed to lack (Heilman, 1995; Weichselbaumer, 2004; Van Vianen and Willemsen, 1992). The third set of hypotheses, related to sexual orientation, masculine/feminine personality traits and workplace outcomes, are the following:

Hypothesis 3.a: Personality traits that an applicant should have that are labelled masculine (feminine) are likely to negatively affect the interview invitations gay men (lesbians) receive. 
Hypothesis 3.b: Personality traits that an applicant should have that are labelled masculine (feminine) are likely to negatively affect the entry-level annual salary prospects of gay men (lesbians).

Research also suggests that gradual improvements in terms of legal protections and workplace actions can affect sexual orientation minorities' lives by countering heteronormativity in the workplace and reducing bias against them (Butler, 2004; Giddings and Pringle, 2011). Gay-friendly work environments can facilitate the growth of opportunities for sexual orientation minorities to construct themselves as valued organisational members (Rumens and Kerfoot, 2009). Discourse regarding sexual orientation is perceived as an organisation's policy for engendering a more productive and efficient workforce (Fleming, 2007). Based on these considerations, I suggest that firms that do not provide written commitments to equal opportunity negatively affect the labour market prospects of gay men and lesbians. The fourth set of hypotheses, related to sexual orientation, provision of written commitments to equal opportunities and workplace outcomes, are the following:

Hypothesis 4.a: Firms that do not provide written commitments to equal opportunity are likely to negatively affect the number of invitations gay men and lesbians receive.

Hypothesis 4.b: Firms that do not provide written commitments to equal opportunity are likely to negatively affect gay men's and lesbians’ entry-level annual salaries.

In the current study, by testing the aforementioned hypotheses, I wish to provide knowledge and insight that is relevant to improving our understanding of the labour market reality that gay men and lesbians face. This is the first field experiment on sexual orientation discrimination in hiring in the United Kingdom, and among the first to provide empirical estimates in this context. The study's conceptual framework and the design of this study will enable me to capture in the field employers' evaluations towards applicants of varying sexual orientations. Exploring potential inequality among people of varying sexual orientations is of crucial importance to studying and furthering the rights of all employees.

\section{Methodology}

Correspondence testing is a method for evaluating discrimination in natural settings and is one of the most reliable methods of testing for discrimination in the workplace (Riach and Rich, 2002). A typical correspondence test involves sending carefully matched pairs of written job applications (i.e., cover letter and $\mathrm{CV}$ ) in response to advertised vacancies to test for hiring discrimination in the labour market at the initial stage of interview selection (Riach and Rich, 2002). Studies match applications on attributes such as sex, age, education, experiences and marital status. Applications must be similar in all relevant respects, so that the only characteristic that differs between two applications is the one that signals membership in a group (Weichselbaumer, 2003). Then, the two applications are sent to the same firm. The degree of discrimination is measured by calculating the difference in the number of invitations for interviews that members of each group receive (Riach and Rich, 2002). Correspondence testing provides clear evidence of discrimination because the impact of unobserved differences in employee productivity, motivation, commitment and personal bias cannot affect firms' screening processes compared with studies of 
employment differences and studies that evaluate qualitative data on discriminatory experiences (see Riach and Rich, 2002; Weichselbaumer, 2003).

In the current study, I randomly chose one university per United Kingdom region (12 first-level regions within the state, based on the Nomenclature of Territorial Units of Statistic geocode standard). In September 2012, I contacted the universities’ student unions, and I provided details of the intent and purpose of the designed survey and kindly requested their cooperation. The collaboration with the 12 university student unions led to an announcement that was posted in student union areas. The announcement asked third-year undergraduates who were interested in searching for work to voluntarily take part in applied research beginning in January 2013, with the aim of the research being to evaluate how demographic characteristics affect applicants' labour market outcomes.

In the announcement, I explained that, for a period of eight weeks, I would provide each participant with up to 50 random job openings relative to their studies and record the correspondence from firms, noting in particular invitations for interviews. I mentioned that the participants would have the option of applying only for those jobs that were of interest to them. In addition, acceptance of interviews would be at their discretion. Employers would not have knowledge of the experiment. The announcement invited potential participants to contact me, to send me their applications (cover letters and CVs) for review, and to create a new university email account for research purposes, to which I would have access by default. The students had to include in their CVs personal characteristics (demographic characteristics), pre-university qualifications, courses studied and grade degree, workplace experience, membership in university unions and their specific role in the unions, skills, personality characteristics, and hobbies. In addition, potential participants were invited to ask any questions they might have had regarding the purposes of the research. In addition, it was mentioned that the participants would receive a certification regarding their experience in research design, data gathering, database creation and estimations after submitting the successful deliverables.

\section{Sexual Orientation Labelling}

By the end of November 2012, I had received 2,312 CVs from students. The students' descriptive statistics are shown in Table 1. In 258 (11.1\%) CVs, students indicated that they had experience as members of their universities' gay and lesbian unions. That is, I attempted to identify students who were voluntarily 'out'. I shortlisted those CVs that mentioned a specific role in gay and lesbian unions; the majority of gay and lesbian union members stated that they had acquired organisational skills—for example, event planning, public speaking and budgeting skills—-through membership in these organisations. In this study, I worked with students who stated that they were the ones responsible for their unions' budgets and that they had thereby acquired financial and fundraising skills. I assumed that managing the unions' financial operations would be relevant job experience on students' CVs, signalling more than just their sexual orientation. Students could be seen as having valuable experience with important transferable skills by emphasising this activity. Appendix I provides a general version of the cover letter and CV.

[Table 1] 
Then, I matched students who did not mention gay and lesbian union membership with students who did mention such membership. Pairs had to be comparable across relevant characteristics, so that any systematic difference in treatment could most likely be attributed to the effects of gay and lesbian union membership or sexual orientation. I considered a number of criteria during the CV screening period to minimise the heterogeneity of the CVs. I matched CVs on attributes such as sex, coursework, age, ethnicity, marital status, and student union membership.

The students I worked with had the mean characteristics of the total sample $(2,312)$ : they were 21 years old (3rd-year students), British nationals and unmarried. The students studied economics, psychology, or education (primary). Although I received applications from students who were studying multiple courses, I made matches considering the age, sex, ethnicity, and grade. Satisfying these criteria, I identified students who were studying the aforementioned three courses. All students had an expected upper second-class honour (i.e., 2:1, 61\%). The assigned mean characteristics of United Kingdom university students are consistent with those of the major United Kingdom studies (Brennan and Winnie, 2008). In addition, students did not have any paid work experience. Each of the students had a mobile telephone number, a postal address, and a university email address. In all cases, the students declared the place of their studies as their city of residence. I matched addresses on the basis of postal code to indicate the same social class.

In addition, I matched CVs based on students' skills, self-reported personality characteristics, and spare-time interests, all of which students included in their CVs. The students I worked reported similar skills (i.e., ability to work in teams, communication skills), personality characteristics (i.e., friendly and likeable), and spare time interests (i.e., cinema and music). Regarding the personality characteristics, friendly and likeable were evaluated as neutral, i.e., as neither feminine nor masculine based on Bem's (1974; 1981) masculinity-femininity inventory. Bem’s (1974; 1981) inventory provides 60 traits; twenty are classified as masculine, twenty are classified as feminine, and twenty are classified as neutral. Based on Bem's (1974; 1981) theoretical predictions, traits are called neutral if they are evaluated to be suitable for both men and women in society. However, traits are masculine if they are evaluated to be more suitable for men than women in society (for example, being competitive or acting as a leader). Finally, feminine traits are those that are evaluated to be more suitable for women than men (for example, being gentle and cheerful). Recent attempts to validate the contents of the Bem Sex-Role Inventory have provided evidence for the persistence of these stereotypes across different countries (Ozkan and Lajunen, 2005; Xiumei et al., 2012).

Importantly, to ensure that any differences in treatment could be attributed to sexual orientation bias, I matched CVs that mentioned gay and lesbian university union membership with CVs that mentioned human rights union membership (see Tilcsik, 2011). Similar to students with gay and lesbian union membership, I worked with students who noted that they were responsible for their university's human rights unions' budgeting. These students mentioned in their CVs that they had gained financial expertise through this activity. CVs that noted human rights union membership were carefully chosen to avoid suggestions of differences in applicants' levels of human capital, which could have made it difficult to assess the extent of bias. Both gay and lesbian and human rights student unions have the same goal: to raise awareness of human rights abuses. Under the study design, it is difficult to suggest that employers may perceive managing a 
human rights union's financial operations as more valuable experience than managing a gay and lesbian union's financial operations, even if these employers are not biased with respect to sexual orientation. However, it is unlikely that managing a human rights union's budget is more radical or liberal than managing a gay and lesbian union's budget. Specifically, the application that students submitted to the firms noted: "I have gained organisational and financial skills by administrating my university’s (gay and lesbian/human rights) union. I was responsible for the budget, and I also had fundraising responsibilities", with the "gay and lesbian/human rights” descriptor distinguishing the two groups of students.

At the end of the screening and matching procedure, I created 6 matched pairs for each of the 12 universities (i.e., 144 students in total). The first matched pair consisted of a heterosexual man and a gay man who were studying economics. The second matched pair consisted of a heterosexual man and a gay man who were studying psychology. The third matched pair consisted of a heterosexual man and a gay man who were studying education (primary). The fourth, fifth and six matched pairs consisted of heterosexual women and lesbian women who were studying economics, psychology and education (primary), respectively.

Working with human resources departments, I conducted internal pre-tests to ensure that neither the two cover letters nor the CVs that formed a pair would elicit preferences. The students applied for entry-level jobs relative to their studies in their city by sending out their application forms. I identified the vacancies through a random sample of advertisements that appeared on fifteen leading United Kingdom internet websites that advertised job openings. The large number of job search websites leads me to suggest that these may be a typical resource for the average job seeker. The occupations covered a large spectrum of work environments, such as accounting, banking, education, and social care, and because I forwarded to each student job openings relative to her/his studies, I ensured correspondence between applicants' courses and job applications. For instance, those who studied economics applied for accounting and banking jobs.

After I made the matches, I contacted the 144 students to clarify the study's steps, the application screening process, the matching criteria, and the application submission process. One hundred per cent of the students chose to participate in the field study, and I asked them to provide me with signed forms indicating their willingness to participate. Additionally, at the end of the study, I asked students whether they had experienced any emotional disturbances as a result of the study; none of the students reported adverse feelings during the research period.

\section{Application Sending}

The application submission process lasted from of the beginning of February 2013 to of the beginning of April 2013. Throughout this period, I provided random job openings to the students two days per week. Having access to their email accounts, I recorded whether each member of the pair had applied to the same firm, the day and hour that applications were sent, and invitations for interviews or rejections. The firms communicated with the applicants via email.

After the data-gathering period, the evaluation showed that in $74.6 \%(5,549)$ of cases, both members of the pairs had applied for the same jobs, and I used these observations (i.e., the paired observations). By doing so, I minimised the job and occupation heterogeneities that could have affected applicants' 
employment prospects. For research purposes, I also recorded the entry-level annual salaries and the characteristics of the jobs and firms. To collect this specific information, I adopted the following process. If a job opening or a firm's official website indicated a job’s or firm's characteristics (for example, the entrylevel annual salary), the information was registered. When limited information was provided, research assistants contacted the firms and collected the relevant data, stating that were engaged in a university study of the firm environments behind advertised job openings. Notably, in all conversations, the relevant managers promptly provided brief descriptions of their firms, including the provision of written equal opportunity standards.

Finally, to identify stereotypically male and female heterosexual traits, I followed the procedures used by Weichselbaumer (2004) and Tilcsik (2011). Using the Bem Sex-Role Inventory (Bem, 1974; 1981) presented before, I screened each job opening and recorded whether it described the ideal job applicant as masculine or feminine. Appendix II provides the variables’ coding.

\section{Descriptive Statistics: Firms and Job Openings}

In this section, I provide the descriptive statistics for the jobs and firms with vacancies that the study's participants applied to (5,549 cases). This sample is characterised by a wide range of jobs in accounting, banking, finance and management (38.4\%); education and teaching (26.1\%); and social care, social services and charities (35.3\%). Regarding the characteristics of job openings, the average entry-level annual salary was $£ 23,031$. In addition, $18.5 \%$ of the firms offered fixed contracts, $36.1 \%$ were in the public sector, and $4.9 \%$ offered relocation packages. Furthermore, 31.5\% of the firms were multinational, $70.4 \%$ had human resources departments, $61.3 \%$ had a formal written equal opportunity policy, and $62.1 \%$ had trade unions. A total of $82.1 \%$ of the firms employed over 200 people, and $78.5 \%$ had been established for over 20 years. As expected, there was regional variety; for instance, $11.5 \%$ of the firms were located in London, 10.1\% were located in the east of England, and 9.3\% could be found in Wales.

\section{Descriptive statistics: Invitations to Interviews and Entry-Level Annual Salaries}

The outcomes related to invitations for interviews are displayed in Table 2 for men and in Table 3 for women. The correspondence testing outcomes are set out in a format following McIntosh and Smith (1974), which has since been adopted in field experiments across Europe (Riach and Rich, 2002). As observed in the last line of Table 2, net discrimination against gay men was found in 151 cases, a rate of 8.3\% ( $\mathrm{p}<0.001)$. Table 3 reflects that net discrimination against lesbians was $8.4 \%(\mathrm{p}<0.001)$. The statistical significance of all findings of net discrimination was determined using the chi-squared test (Heckman and Siegelman, 1993).

Based on the Office for National Statistics report (2013), the occupations for which the students applied were characterised by differing sex ratios. Jobs in accountancy, banking, finance and management represent male-dominated occupations (64\% of employees are men). By contrast, jobs in education and teaching and in social care, social services and charity represent female-dominated occupations (79\% and 73\%, respectively, of employees in these fields are women). In Tables 2 and 3, the correspondence testing 
outcomes for men and women are also presented by occupation. In Table 2, the statistics for men suggest that gay men face higher net discrimination in male-dominated occupations (10.9\%; $\mathrm{p}<0.001)$. Similarly, in Table 3, the statistics for women suggest that lesbians face higher net discrimination in female-dominated occupations (10.1\%; $\mathrm{p}<0.001)$.

\section{[Table 2] - [Table 3]}

Table 4 presents the entry-level annual salaries for those who received invitations for interviews. The sample employed in this study consisted of 1,810 observations for heterosexual men and 1,659 observations for gay men. Although gay male participants were similar to their heterosexual counterparts in age, education level, and work experience, the statistics suggest that male heterosexual applicants were offered prospective annual salaries that were, on average, higher than those that were offered to gay men: $£ 23,544$ versus $£ 23,072$. The sexual orientation salary difference disadvantaged gay men by approximately $2 \%(\mathrm{p}<0.001)$. Moreover, the sexual orientation salary difference disadvantaged lesbians by approximately $1.4 \%(\mathrm{p}<0.001)$. Finally, the statistics suggest that gay men face lower salary prospects in male-dominated occupations $(2.4 \%$; $\mathrm{p}<0.01)$ and that lesbians face lower salary prospects in female-dominated occupations $(1.7 \%$; $<<0.01)$.

\section{[Table 4]}

\section{Estimation Framework}

The probability of an applicant's receiving a job interview was estimated using a linear probability model: $\mathrm{Y}_{\mathrm{i}}=\mathrm{b}_{0}+\mathrm{b}_{1}$ Sexual Orientation $+\mathrm{b}_{2}$ Occupational Controls $+\mathrm{b}_{3}$ Labelled masculine/feminine personality traits $+b_{4}$ Non-existence of equal opportunities $+b_{5}$ Vector of controls $+e$, where $\mathrm{Y}$ is the latent linear probability regression that explained the probability of receiving a job interview; $b_{0}$ is a constant; $b_{1}$ measures sexual orientation; $b_{2}$ controls for occupational effects/male-/female-dominated occupations; $b_{3}$ controls for labelled masculine/feminine personality traits; $b_{4}$ controls for the non-existence of an equal opportunity statement; $b_{5}$ is a vector of controls that accounts for university characteristics, job and firm effects, location effects, and study effects; e is a disturbance term; and i refers to the individual.

In Table 5, Panels I and III, I estimate the aforementioned equation of male and female applicants who were offered a job interview and present the marginal effects (average marginal effects). In Panels II and IV, I use the aforementioned equation to estimate an ordinary least-squares log regression of male and female applicants' entry-level annual salaries. Regarding Hypothesis 1.a, if $b_{1}=0$, gay/lesbian and heterosexual applicants had the identical probability of obtaining interviews. If $b_{1}<0$, the gay/lesbian applicants had a lower probability of obtaining interviews and vice versa. The same reasoning holds for Hypothesis 1.b. That is, if $b_{1}<0$, the gay/lesbian applicants received invitations for interviews at firms that offered lower entry-level annual salaries than those firms that invited heterosexuals for interviews. To test the remainder of the hypotheses, I estimate interaction effects to examine whether sexual orientation interacts with male-/female-dominated occupations (Hypotheses 2.a-2.d), personality characteristics that are labelled masculine/feminine (Hypotheses 3.a-3.b), and the non-existence of equal opportunity statements 
(Hypotheses 4.a-4.b) in affecting sexual orientation minorities' invitations for interviews and entry-level annual salaries ${ }^{1}$.

\section{Hypotheses Estimation}

In Table 5, the study's estimations are presented. Panel I suggests a negative relationship between gay sexual orientation and invitations for interviews. Specifically, gay applicants had a $5 \%(p<0.001)$ lower probability of receiving invitations for interviews than did comparable heterosexual applicants. The estimates provide evidence that when two similar applicants—one homosexual and the other heterosexual—engage in identical job searches, the gay applicant receives fewer invitations for interviews than his heterosexual counterpart. This result implies that gay men are discriminated against when actual employers make hiring decisions. The pattern also suggests that gay men must spend more time than heterosexual men seeking interviews because the same observable signal was more precise for heterosexual men than for gay men. Moreover, in Panel III, the estimates suggest that for female applicants, the patterns discerned are comparable with those for male applicants and can be similarly interpreted. Lesbians receive fewer invitations for interviews on the order of $5.1 \%(\mathrm{p}<0.001)$ when their sexual orientation is labelled in the hiring stage. Based on these outcomes, Hypothesis 1.a is supported: gay men and lesbians are more likely to receive fewer invitations for interviews than heterosexuals.

\section{[Table 5]}

Moreover, Panel II presents the entry-level annual salary estimations for men. The estimates suggest that sexual orientation affects applicants’ annual salary prospects. Gay applicants are invited for interviews by firms that pay salaries that are $1.9 \%(\mathrm{p}<0.001)$ lower on average than those paid by firms that invite heterosexual applicants for interviews. Panel IV offers the entry-level annual salary estimations for women. The results are consistent with those for male applicants and verify the general patterns that were observed. When lesbian sexual orientation is labelled in the recruitment stage, applicants are invited for interviews by firms that pay salaries that are $1.2 \%(\mathrm{p}<0.001)$ lower on average than those paid by firms that invite heterosexual applicants. Thus, Hypothesis 1.b is supported: gay men and lesbians are likely to face lower entry-level annual salary prospects than heterosexuals.

In Panel I, it is clear that gay applicants who submitted CVs for both accounting, banking, finance, and management jobs and social care, social services and charity jobs faced lower probabilities of obtaining interviews than their heterosexual counterparts. The largest difference was observed in the former group of jobs (2.7\%; $\mathrm{p}<0.01)$. Panel II indicates that lesbians also receive fewer invitations for interviews in all occupations than heterosexual women. For lesbians, the largest difference was observed in social care, social services and charity jobs $(2.8 \%$; $\mathrm{p}<0.01)$. It appears that in the present sample, gay men received the fewest

\footnotetext{
${ }^{1}$ In this study, I corrected for the intra-class correlation that appeared. Two applicants contacted the same firm. Thus, the probability of the heterosexual applicant's receiving an invitation to interview was correlated with the probability of the gay man or lesbian applicant's receiving an invitation to interview. In the estimations that follow, I report robust-clustered standard errors. In addition, sample selection was not an issue. Salaries were observed from the beginning (the information was provided in the job advertisement), that is, before an applicant had received the invitation for an interview or a job offer.
} 
invitations for interviews in traditionally male-dominated occupations, whereas lesbians received the fewest invitations for interviews in traditionally female-dominated occupations. Thus, Hypotheses 2.a and 2.b are supported. However, in Panels II and IV, the estimations suggest that there was no statistically significant correlation between entry-level annual salaries for gay men (lesbians) and male-dominated (femaledominated) occupations. Thus, Hypotheses 2.c and 2.d are not supported.

Furthermore, in Panel I, the estimates show that gay men received fewer invitations for interviews for jobs in which masculine personality traits were highlighted in the job applications (by 1.9\%; $\mathrm{p}<0.05$ ). In Panel III, the estimates show that lesbians received fewer invitations for interviews for jobs in which feminine personality traits were highlighted in the job applications (by $1.5 \%$; $\mathrm{p}<0.05$ ). Hypothesis 3.a is thus supported. However, in Panels II and IV, the estimations suggest a statistically insignificant correlation between entry-level annual salaries for gay men and lesbians and the emphasis on masculine/feminine personality traits in job descriptions. Hypothesis 3.d is therefore rejected.

Moreover, in Panel I, the regression results suggest that gay applicants receive fewer invitations for interviews to firms that do not have written commitments to equal opportunity $(1.1 \%$; $p<0.01)$. The same negative pattern holds for lesbians $(1.2 \%$; $<<0.01)$. Hypothesis $4 . a$ is therefore supported. However, the entry-level annual salaries of gay men and lesbians did not appear to be affected in a statistically significant way by the non-existence of written commitments to equal opportunities. Hypothesis 4.b is thus rejected. Finally, regarding the study's controls, the order in which the application was sent, the cover letter, and the CV type did not appear to statistically affect the applicants' interview invitation rates or their entry-level annual salaries. Full estimations are available on request.

\section{Discussion and Conclusions}

I have proposed a field approach to determining whether sexual orientation affects first-time job seekers' probabilities of obtaining invitations for interviews and their entry-level annual salaries in the United Kingdom. The strength of this study lies in of the fact that it applies a field design to a real-world setting, which enables an evaluation of how firms treat applicants in the recruiting process. Working in the field between February and April 2013, with 144 students from 12 randomly selected universities and recording their correspondence with 5,549 firms, I obtained a number of statistically significant results. Controlling for various characteristics, the estimations suggest that sexual orientation, which was identified by students' participation in gay and lesbian university student unions, affects the probability of obtaining invitations to vacancies and entry-level salaries. The study's outcomes for both gay men and lesbians are consistent with the findings of other field experiments in the European Union and the United States on sexual orientation that this study reviewed. Despite the introduction of anti-discrimination labour legislation in the United Kingdom in 2010, the findings show a statistically significant negative effect of gay and lesbian orientation on employment prospects. The Equality Act of 2010 (National Archives (2010) consolidated antidiscrimination legislation in the United Kingdom into one statute. Under the Equality Act, it is unlawful to discriminate on the grounds of someone's sexual orientation or perceived sexual orientation. This applies to all aspects of employment, including recruitment, promotion, training, terms and conditions, pay and benefits 
and dismissals (Equality and Human Rights Commission, 2009). Unfortunately, however, studies suggest that judicial and legislative protection of sexual orientation minorities constitute only a small step in improving their well-being and highlight the need for further theoretical and empirical evaluation and policy interventions (Ellison and Gunstone, 2009).

In the current study, based on post-structuralist research, I assume that deviation from heteronormativity creates a basis for workplace discrimination (Ward and Winstanley, 2003; Martinsson, et al., 2007). The findings suggest that heteronormative discourse may continue to be reproduced within United Kingdom workplaces and that it negatively affects the lived experiences of gay and lesbian job applicants. Studies suggest that as long as employers' biases towards sexual orientation minorities persist, the extent of unequal treatment will be directly proportional to the strength of this bias (Becker, 1957; England, 1994; Jaret, 1995; Charles and Guryan, 2008). As a result, employers may not invite gay men and lesbians to be interviewed, or gay men and lesbians may be invited to be interviewed primarily for positions that offer relatively low entry-level annual salaries, thus equalising the unit costs of labour after factoring in antipathy towards homosexuals (England, 1994; Jaret, 1995).

In addition, the results reveal that gay men receive significant fewer invitations for interviews in traditionally male-dominated fields and lesbians receive significant fewer invitations for interviews in traditionally female-dominated fields. It thus appears that gender assumptions affect United Kingdom sexual orientation minorities' labour market prospects. These results are consistent with those of other studies (Ahmed et al., 2013; Morgan, 1992; Williams, 1993). Furthermore, the findings reveal that gay applicants receive fewer invitations for interview for jobs for which masculine personality traits are highlighted in the job applications, and lesbians receive fewer invitations to interview for jobs for which feminine personality traits are highlighted. United Kingdom firms appear to maintain stereotypical notions when gays and lesbians apply for jobs, which is a pattern that international studies over the last thirty years (e.g., Heilman, 1984; Glick, et al, 1988; Weichelbaumer, 2003; 2004; Tilcsik, 2011) have also identified. Furthermore, the results suggest that gay and lesbian applicants receive fewer invitations for interviews from firms that do not provide written commitments to equal opportunity. The present study thus concludes that industrial characteristics might affect sexual orientation minorities' labour market prospects. Anti-discrimination legislation and governmental equality campaigns may be an appropriate response to sexual orientation bias in the labour market; however, firms should develop their own equality schemes and official procedures that address sexual orientation.

Despite measures to encourage openness and discourage discrimination, it is evident that sexual minorities encounter serious misconceptions and barriers in the job market. Employers should more strongly support the equality of sexual minorities and be explicit about the unacceptability of discrimination. Workplaces should take steps to prevent discrimination and actively encourage gay and lesbian employees to be themselves in the workplace. Studies suggest that good relations between employers and employees increase the openness of sexual orientation minorities, improve job attitudes, and benefit firms as a whole because teamwork is an important aspect of firm productivity and success (Day and Schoenrade, 2000; Huffman, et al., 2008; McLaren et al., 2013; Rumens and Kerfoot, 2009; Ozeren, 2014). In addition, firms 
should understand the strategic benefit of fully realising the talents of all employees and the ethical mandate of promoting equal opportunity and fairness for all (Day and Schoenrade, 2000). Recognition from both management and co-workers provides external reinforcement of an employee's developing competence and self-esteem (Rumens and Kerfoot, 2009).

The current evidence suggests the presence of sexual orientation discrimination and labour market characteristics on employment for gay and lesbian individuals in the United Kingdom. Importantly, however, I cannot generalise the results to other types of job applicants, vacancies, employers, or cultures without further research. The current findings are strictly applicable only to the time and place from which the sample was drawn. In addition, this study focuses on the hiring stage and ignores potential discrimination that could arise at later stages. Although I found no correlation (i) between entry-level annual salaries for gay men (lesbians) and male-dominated (female-dominated) occupations, (ii) between entry-level annual salaries for gay men and lesbians and emphasising masculine/feminine personality traits in the job descriptions and (iii) between the entry-level annual salaries of gay men and lesbians and the non-existence of written commitments to equal opportunities, these differentials may exist elsewhere in the labour market. Because of the data selection and the experimental methodology, these results might not accurately characterise the potential earning differential that employed gay men and lesbians face in the United Kingdom when working in male-/female-dominated occupations that require certain personality traits. If gay men and lesbian employees experience losses in earnings because they face glass ceilings because of the non-existence of written commitments to equal opportunities, estimates based on starting positions will not be sensitive to these effects. Finally, in reality, job offers are also obtained via informal searches and networks. This omission could also qualitatively affect the results. 


\section{References}

Adam, B. D. (1981). Stigma and Employability: Discrimination by Sex and Sexual Orientation in the Ontario Legal Profession. Canadian Review of Sociology and Anthropology, 18: 216-221.

Ahmed, A. M. Andersson, L. and Hammarstedt, M. (2013). Are Gay Men and Lesbians Discriminated Against in the Hiring Process? Southern Economic Journal, 79: 565-585.

Arabsheibani, R. G. Marin, A. and Wadsworth, J. (2004). In the Pink: Homosexual-Heterosexual Wage Differentials in the UK. International Journal of Manpower, 25: 343-354.

Arabsheibani, R. G. Marin, A. and Wadsworth, J. (2005). Gay Pay in the UK. Economica, 72: 333-347.

Badgett, L. M. V. Lau, H. Sears, B and Ho, D. (2007). Bias in the Workplace: Consistent Evidence of Sexual Orientation and Gender Identity Discrimination. The Williams Institute, UCLA School of Law. Becker, G. S. (1957). The Economics of Discrimination. Chicago: University of Chicago Press.

Bem, S. L. (1974). The Measurement of Psychological Androgyny. Journal of Consulting and Clinical Psychology, 42: 155 - 162.

Bem, S. L. (1981). Bem Sex Role Inventory: Professional Manual. Palo Alto, CA: Consulting Psychologists Press.

Brennan, J. and Winnie, T. (2008). The Employment of UK Graduates: Comparisons with Europe. London: The Open University.

Broadbridge, A. and Hearn, J. (2008). Gender and Management: New Directions in Research and Continuing Patterns in Practice. British Journal of Management, 19: 38-49.

Bruni, A. (2006). 'Have You Got a Boyfriend or Are You Single?’: On the Importance of Being 'Straight' in Organizational Research. Gender, Work and Organization, 13: 299-316.

Butler, J. (1990). Gender Troubles. Routledge: New York.

Butler, J. (2004). Undoing Gender. Routledge: London.

Carpenter, C. (2008). Sexual Orientation, Work, and Income in Canada. Canadian Journal of Economics, 41: 1239-1261.

Charles, K. K. and Guryan, J. (2008). Prejudice and Wages: An Empirical Assessment of Becker's The Economics of Discrimination. Journal of Political Economy, 116:773-809.

Connell, R. (2005). Masculinities. Cambridge: Polity.

Chung, Y. and Harmon, L. (1994). The Career Interests and Aspirations of Gay Men: How Sex-Role orientation is Related. Journal of Vocational Behaviour, 45: 223-239.

Collins, C. J. (2013). Stress and Safety for Gay Men at Work within Masculinized Industries. Journal of Gay and Lesbian Social Services, 25: 245-268.

Crow, S. M. Fok, L. Y. and Hartman, S. J. (1998). Who is at Greates Risk of Work-Related DiscriminationWomen, Blacks, or Homosexuals? Employee Responsibilities and Rights Journal, 11: 15-26.

Connell, R. (2000). The Men and the Boys. Cambridge Polity Press.

Day, N. E. and Schoenrade, P. (2000). The Relationship Among Reported Disclosure of Sexual Orientation, Anti-Discrimination Policies, Top Management Support and Work Attitudes of Gay and Lesbian Employees. Personnel Review, 29: 346-363. 
Donnelly, J. (1999). Non-Discrimination and Sexual Orientation. Making a Place for Sexual Minorities in the Global Human Rights Regime. In Baehr, P. Flinterman, C. and Senders, M. (Eds). Innovation and Inspiration. Fifty Years of the Universal Declaration of Human Rights (pp. 93-110). Amsterdam: Royal Netherland Academy of Arts and Sciences.

Drydakis, N. (2009). Sexual Orientation Discrimination in the Labor Market. Labour Economics, 16: 364372.

Drydakis, N. (2011). Women's Sexual Orientation and Labor Market Outcomes in Greece. Feminist Economics, 11:89-117.

Drydakis, N. (2015). Effect of Sexual Orientation on Job Satisfaction: Evidence from Greece, Industrial Relations: A Journal of Economy and Society, 54: 162-187.

Ellison, G. and Gustone, B. (2009). Sexual Orientation Explored: A Study of Identity, Attraction, Behaviour and Attitudes in 2009. Manchester: Equality and Human Rights Commission.Employment Market Analysis and Research. (2009). Fair Treatment at Work Survey. London: EMAR.

England, P. (1994). Neoclassical Economists' Theories of Discrimination, in Burstein, P., (ed.), Equal Employment Opportunity: Labor Market Discrimination and Public Policy. New York: Walter de Gruyter.Equality and Human Rights Commission. (2009). How Fair is Britain? Manchester: EHRC.

National Archives (2010). Equality Act 2010 (c. 15). Surrey: The National Archives.

Equality Challenge Unit. (2009). The Experience of Lesbian, Gay, Bisexual and Trans Staff and Students in Higher Education. ECU: London.

European Union Agency for Fundamental Rights. (2009). Homophobia and Discrimination on Grounds of Sexual Orientation and Gender Identity in the European Union Member States, Part II-The Social Situation. Vienna.

Frank, J. (2006). Gay Glass Ceiling. Economica. 73: 485-508.

Fleming, P. (2007). Sexuality, Power and Resistance in the Workplace. Organization Studies, 28: 239-256.

Foster, T. and Newman, E. (2005). Just a Knock Back? Identity Bruising on the Routeto Becoming a Male Primary School Teacher. Teachers and Teaching: Theory and Practice, 11: 341-358.

Foucault, M. (1980). The Confession of the Flesh. In: Garden, C. (Fd.) Power/ Knowledge: Selected Interviews and Other Writings 1972-1977 (pp.194-228). Brighton: Harvester Press.

Foucault, M. (2001). The Order of Things. London: Routledge.

Foucault, M. (1990). The History of Sexuality: An Introduction. New York: Knopf.

Gates, T. G. and Viggiani, P. A. (2013). Understanding Lesbian, Gay, and Bisexual Worker Stigmatization: A Review of the Literature. International Journal of Sociology and Social Policy, 34: 359-374.

Giddings, L. S. and Pringle, J. K. (2011). Heteronormativity at Work: Stories from Two Lesbian Academics. Women’s Studies Journal, 25: 91-100.

Glick, P. Zion, C. and Nelson, C. (1988). What Mediates Sex Discrimination in Hiring Decisions. Journal of Personality and Social Psychology, 55: 178-186.

Guasp, A. (2009). The Teachers' Report: Homophobic Bullying in Britain's Schools. London: Stonewall. 
Gusmano, B. (2008). Coming Out or Not? How Non-Heterosexual People Manage Their Sexual Identity at Work. Journal of Workplace Rights, 13: 473-496.

Heilman, M.E. (1995). Sex Stereotypes and their Effects in the Workplace: What we Know and What we Don't Know. Journal of Social Behavior and Personality, 10: 3-26.

Heckman, J. J. and Siegelman, P. (1993). The Urban Institute Audit Studies: Their Methods and Findings, in Fix, M. E. and Struyk, R. J. (Eds.). Clear and Convincing Evidence: Measurement of Discrimination in America. Washington, DC: Urban Institute Press.

Herek, G. M. (2004). Beyond Homophobia: Thinking aboit Sexual Prejudice and Stigma in the Twenty-First Century. Sexuality Research and Social Policy: Journal of NSRC. 1: 6-24.

Hird, M. J. (2004). Sex, Gender and Science. Basingstoke: Palgrave.

Huffman, A. H. Watrous-Rodriguez, K. M. and Eden B. King, E. B. (2008). Supporting a Diverse Workforce: What Type of Support is Most Meaningful for Lesbian and Gay Employees? Human Resource Management, 47: 237-253.

Hunt, R. and Jensen, J. (2007). The Experience of Young Gay People in Britain's Schools. London; Stonewall.

Hook, M. K. and Bowman, S. (2008). Working for a Living: The Vocational Decision Making of Lesbians. In Brand, P. (Ed.), Lesbians and Work: The Advantages and Disadvantages of Comfortable Shoes (pp. 85-95). Binghamton, NY: The Haworth Press.

Jaret, C. (1995). Contemporary Racial and Ethnic Relations. New York: Harper Collins.

Madon, S. (1997). What do People Believe About Gay Males? A Study of Stereotype Content and Strength. Sex Roles, 37: 663-685.

Martinsson, L. Reimers, E. Reingarde, J. Lundgren, A. S. (2007). Norms at Work: Challenging Homophobia and Heteronormativity. Sweden: The Transnational Cooperation for Equality.

McIntosh, N. and Smith, D. (1974). The Extent of Racial Discrimination, Political and Economic Planning Broadsheet no. 547. London: Political and Economic Planning.

McLaren, S. Gibbs, P. M. Watts, E. (2012). The Interrelations Between Age, Sense of Belonging, and Depressive Symptoms Among Australian Gay Men and Lesbians. Journal of Homosexuality, 60: $1-15$.

Morgan, D. (1992). Discovering Men. London: Routledge.

National Union of Students. (2009). Inclusive Students' Unions: Equality and Diversity in Practice. NUS: London.

Office for National Statistics. (2013). Women in the Labour Market. Newport: Office for National Statistics.

Ozeren, E. (2014). Sexual Orientation Discrimination in the Workplace: A Systematic Review of Literature. Procedia-Social and Behavioral Sciences, 109: 1203-1215.

Ozkan, T. and Lajunen, T. (2005). Masculinity, Femininity, and the BEM Sex Role Inventory in Turkey. Sex Roles, 52: 103-110.

Ozturk, M. B. (2011). Sexual Orientation Discrimination: Exploring the Experiences of Lesbian, Gay and Bisexual Employees in Turkey. Human Relations, 64: 1099-1118. 
Pager, D. D. and Karafin, D. (2009). Bayesian Bigot? Statistical Discrimination, Stereotypes, and Employer Decision Making. ANNALS of the American Academy of Political and Social Science, 621: 7093.

Petersen, T. Saporta, I.and Seidel, L. M. D. (2000). Offering a Job: Meritocracy and Social Networks. American Journal of Sociology, 3: 763-816.

Prasad, A. (2012). Beyond Analytical Dichotomies. Human Relations, 65: 567-595.

Pringle, J. K. (2008). Gender in Management: Theorizing Gender as Heterogender. British Journal of Management, 19: 110-119.

Ragins, B. Cornwall, J. M. and Miller, J. S. (2003). Heterosexism in the Workplace: Do Race and Gender Matter? Group and Organization Management, 28: 45-74.

Riach, P. A. and Rich, J. (2002). Field Experiments of Discrimination in the Market Place. The Economic Journal, 112: 480-518.

Rumens, N. and Kerfoot, D. (2009). Gay men at Work: Reconstructing the Self as Professional. Human Relations, 62:763-786.

Rumens, N. (2010). Workplace Friendships Between Men: Gay Men’s Perspectives and Experiences. Humans Relations, 63: 1541-1562.

Rumens, N. (2012). Queering Cross-Sex Friendships: An Analysis of Gay and Bisexual Men’s Workplace Friendships With Heterosexual Women. Humans Relations, 65: 955-978.

Tilcsik, A. (2011). Pride and Prejudice: Openly Gay Men and Employment Discrimination. American Journal of Sociology, 117: 586-626.

Van Vianen, A. E. and Willemsen, T. M. (1992). The Employment Interview: The Role of Sex Stereotypes in the Evaluation of Male and Female Job Applicants in the Netherlands. Journal of Applied Social Psychology, 22: 471 - 491.

Ward, J. and Winstanley, D. (2003).The Absent Presence: Negative Space within Discourse and the Construction of Minority Sexual Identity in the Workplace. Human Relations, 56: 1255-1280.

Weichselbaumer, D. (2003). Sexual Orientation Discrimination in Hiring. Labour Economics 10: 629-642.

Weichselbaumer, D. (2004). Is it Sex or Personality? The Impact of Sex Stereotypes on Discrimination in Applicant Selection. Eastern Economic Journal, 30: 159-186.

Williams, C. (1993). Doing Women’s Work: Men in Non-Traditional Occupations. London: Sage.

Willis, P. (2012). Witnesses on the Periphery: Young Lesbian, Gay, Bisexual and Queer Employees Witnessing Homophobic Exchanges in Australian Workplaces. Human Relations, 65: 1589-1610.

Xiumei, Y. Meifang, W. and Qing, Z. (2012). Effects of Gender Stereotypes on Spontaneous Trait Inferences and the Moderating Role of Gender Schematicity: Evidence from Chinese Undergraduates. Social Cognition, 30: 220-231.

Yep, G. A. (2002). From Homophobia and Heterosexism to Heteronormativity. Journal of Lesbian Studies, 6: 163-176. 
Table 1. Descriptive Statistics; Students' Characteristics

\begin{tabular}{ll}
\hline Categories & Mean \\
\hline Men (\%) & 47.72 \\
Age (continuous variable; years) & 21.18 \\
British-White (\%) & 75.06 \\
Married (\%) & 3.09 \\
Pre-university level qualification; UCAS tariff score (continuous variable) & 482.17 \\
Grade obtained (out of 100) & 60.95 \\
Working experience (in months) & 0.31 \\
Statistical software knowledge (\%) & 86.28 \\
Percentage of applicants that include 'ability to work in team' in their CV & 75.14 \\
Percentage of applicants that include 'communication skills' in their CV & 70.54 \\
Percentage of applicants that include 'friendly' in their CV & 68.18 \\
Percentage of applicants that include 'likeable' in their CV & 72.77 \\
Percentage of applicants that include 'cinema as a hobby' in their CV & 65.32 \\
Percentage of applicants that include 'music as a hobby' in their CV & 68.18 \\
Contact details of two professors to stand as referees (\%) & 72.14 \\
Studies: & \\
Faculty of Humanities and Social Sciences (\%) & 58.18 \\
Faculty of Science and Engineering (\%) & 22.57 \\
Faculty of Health and Life Sciences (\%) & 19.25 \\
University Russell group membership (\%) & 66.66 \\
Gay and lesbian union membership (\%) & 11.18 \\
Human rights union membership (\%) & 29.51 \\
Students' location: & \\
East Midlands (\%) & 9.01 \\
East of England (\%) & 9.43 \\
London (\%) & 8.27 \\
North East (\%) & 8.53 \\
North West (\%) & 6.04 \\
Northern Ireland (\%) & 10.19 \\
Scotland (\%) & 7.20 \\
South East (\%) & 7.82 \\
South West (\%) & 9.36 \\
Wales (\%) & 9.41 \\
West Midlands (\%) & 7.53 \\
Yorkshire and the Humber (\%) & 7.18 \\
\hline Observations & \\
\hline & \\
\hline
\end{tabular}


Table 2. Aggregate Correspondence Test Results; Heterosexual Men vs. Gay Men per Occupation

\begin{tabular}{|c|c|c|c|c|c|c|c|c|c|}
\hline \multirow[t]{2}{*}{ Occupations } & \multirow{2}{*}{$\begin{array}{l}\text { Jobs } \\
\text { No. }\end{array}$} & \multirow{2}{*}{$\begin{array}{l}\text { Neither } \\
\text { invited } \\
\text { No. }\end{array}$} & \multirow{2}{*}{$\begin{array}{l}\text { At } \\
\text { least } \\
\text { one } \\
\text { invite } \\
\text { d } \\
(1) \\
\text { No. }\end{array}$} & \multirow{2}{*}{$\begin{array}{l}\text { Equal } \\
\text { treatment } \\
\text { No. }\end{array}$} & \multirow{2}{*}{$\begin{array}{l}\text { Only } \\
\text { heterosexua } \\
\text { l men } \\
\text { invited } \\
\text { (2) } \\
\text { No. }\end{array}$} & \multirow{2}{*}{$\begin{array}{l}\text { Only gay } \\
\text { men invited } \\
\text { (3) } \\
\text { No. }\end{array}$} & \multicolumn{2}{|c|}{ Net discrimination } & \multirow{2}{*}{$\begin{array}{l}\mathrm{X}^{2} \\
\text { test }\end{array}$} \\
\hline & & & & & & & $\begin{array}{l}(2)-(3) \\
\text { No. }\end{array}$ & $\begin{array}{c}(2)-(3) / 1 \\
\%\end{array}$ & \\
\hline $\begin{array}{l}\text { Accountancy, } \\
\text { banking, } \\
\text { finance and } \\
\text { management }\end{array}$ & 1,127 & 394 & 733 & 659 & 74 & 0 & 74 & 10.09 & $72.01 * * *$ \\
\hline $\begin{array}{l}\text { Education and } \\
\text { teaching }\end{array}$ & 724 & 261 & 463 & 426 & 35 & 2 & 33 & 7.12 & $26.94 * * *$ \\
\hline $\begin{array}{l}\text { Social care, } \\
\text { social services } \\
\text { and charity }\end{array}$ & 963 & 343 & 620 & 568 & 48 & 4 & 44 & 7.09 & $44.08 * * *$ \\
\hline Total & 2,814 & 998 & 1,816 & 1,653 & 157 & 6 & 151 & 8.31 & $147.4^{* * *}$ \\
\hline
\end{tabular}

Note: The null hypothesis is that "Both individuals are treated unfavorably equally often", that is, (2)=(3). ***Significant at the 0.001 level. 
Table 3. Aggregate Correspondence Test Results; Heterosexual Women vs. Lesbians per Occupation

\begin{tabular}{|c|c|c|c|c|c|c|c|c|c|}
\hline \multirow{2}{*}{ Occupations } & \multirow{2}{*}{$\begin{array}{l}\text { Jobs } \\
\text { No. }\end{array}$} & \multirow{2}{*}{$\begin{array}{l}\text { Neither } \\
\text { invited } \\
\text { No. }\end{array}$} & \multirow{2}{*}{$\begin{array}{l}\text { At } \\
\text { least } \\
\text { one } \\
\text { invite } \\
\text { d } \\
(1) \\
\text { No. }\end{array}$} & \multirow{2}{*}{$\begin{array}{l}\text { Equal } \\
\text { treatment } \\
\text { No. }\end{array}$} & \multirow{2}{*}{$\begin{array}{l}\text { Only } \\
\text { heterosexua } \\
\text { l women } \\
\text { invited } \\
\text { (2) } \\
\text { No. }\end{array}$} & \multirow{2}{*}{$\begin{array}{l}\text { Only } \\
\text { lesbians } \\
\text { invited } \\
\\
\text { (3) } \\
\text { No. }\end{array}$} & \multicolumn{2}{|c|}{ Net discrimination } & \multirow{2}{*}{$\begin{array}{l}\mathrm{x}^{2} \\
\text { test }\end{array}$} \\
\hline & & & & & & & $\begin{array}{l}(2)-(3) \\
\text { No. }\end{array}$ & $\begin{array}{c}(2)-(3) /(1) \\
\%\end{array}$ & \\
\hline $\begin{array}{l}\text { Accountanc } \\
\text { y, banking, } \\
\text { finance and } \\
\text { management }\end{array}$ & 1,025 & 348 & 677 & 633 & 43 & 1 & 42 & 6.20 & $39.09 * * *$ \\
\hline $\begin{array}{l}\text { Education } \\
\text { and teaching }\end{array}$ & 707 & 195 & 512 & 462 & 49 & 1 & 48 & 9.37 & $46.08 * * *$ \\
\hline $\begin{array}{l}\text { Social care, } \\
\text { social } \\
\text { services and } \\
\text { charity }\end{array}$ & 1,003 & 391 & 612 & 549 & 63 & 0 & 63 & 10.29 & $61.01^{* * *}$ \\
\hline Total & 2,735 & 934 & 1,801 & 1,644 & 155 & 2 & 153 & 8.4 & $150.6^{* * *}$ \\
\hline
\end{tabular}

Note: The null hypothesis is that "Both individuals are treated unfavorably equally often", that is, (2)=(3). *** Significant at the 0.001 level. 
Table 4. Descriptive Statistics; Entry Level Annual Salaries (£); Men and Women per Occupations

\begin{tabular}{|c|c|c|c|c|c|c|}
\hline Occupations & $\begin{array}{l}\text { Heterosexual } \\
\text { Men }\end{array}$ & Gay men & t-test & $\begin{array}{l}\text { Heterosexual } \\
\text { Women }\end{array}$ & Lesbians & $\mathrm{t}$ - test \\
\hline $\begin{array}{l}\text { Accountancy, } \\
\text { banking, finance } \\
\text { and management }\end{array}$ & $\begin{array}{l}24,716.3 \\
(2,457.2)\end{array}$ & $\begin{array}{l}24,109.5 \\
(2,366.7)\end{array}$ & $2.103^{* *}$ & $\begin{array}{l}24,411.9 \\
(2,342.4)\end{array}$ & $\begin{array}{l}24,139.5 \\
(2,374.5)\end{array}$ & 1.473 \\
\hline $\begin{array}{l}\text { Education and } \\
\text { teaching }\end{array}$ & $\begin{array}{l}23,548.8 \\
(2,217.2)\end{array}$ & $\begin{array}{l}23,121.3 \\
(2,164.3)\end{array}$ & $2.224^{* *}$ & $\begin{array}{l}23,214.6 \\
(2,223.4)\end{array}$ & $\begin{array}{l}22,803.4 \\
(2,160.3)\end{array}$ & $2.121^{* *}$ \\
\hline $\begin{array}{l}\text { Social care, social } \\
\text { services and charity }\end{array}$ & $\begin{array}{l}22,580.1 \\
(2,159.5)\end{array}$ & $\begin{array}{l}22,223.4 \\
(2,118.9)\end{array}$ & $2.042 * *$ & $\begin{array}{l}22,256.8 \\
(2,132.0)\end{array}$ & $\begin{array}{l}21,858.2 \\
(2,193.3)\end{array}$ & $2.116 * *$ \\
\hline Average & $\begin{array}{l}23,544.5 \\
(3,000.4)\end{array}$ & $\begin{array}{l}23,072.8 \\
(2,550.3)\end{array}$ & $4.947 * * *$ & $\begin{array}{l}22,907.1 \\
(2,679.1)\end{array}$ & $\begin{array}{l}22,568.8 \\
(2,443.7)\end{array}$ & $3.383 * * *$ \\
\hline Observations & 1,810 & 1,659 & & 1,799 & 1,646 & \\
\hline
\end{tabular}

Note: Standard deviations are in parentheses. ${ }^{* * *}$ Significant at the 0.001 level. ${ }^{* *}$ Statistically significant at the 0.01 level. 
Table 5. Estimations: Invitations to Interviews and Entry Level Annual Salaries; Men and Women

\begin{tabular}{|c|c|c|c|c|}
\hline & $\begin{array}{l}\text { Panel I } \\
\text { Invitations to } \\
\text { Interviews } \\
\text { Men }\end{array}$ & $\begin{array}{l}\text { Panel II } \\
\text { Entry level } \\
\text { annual salaries } \\
\text { Men }\end{array}$ & $\begin{array}{l}\text { Panel III } \\
\text { Invitations to } \\
\text { Interviews } \\
\text { Women }\end{array}$ & $\begin{array}{l}\text { Panel IV } \\
\text { Entry level } \\
\text { annual salaries } \\
\text { Women }\end{array}$ \\
\hline Sexual orientation & $-0.050(0.012)^{* * *}$ & $\begin{array}{l}-0.019 \\
(0.003) * * *\end{array}$ & $-0.051(0.008)^{* * *}$ & $-0.012(0.003)^{* * *}$ \\
\hline $\begin{array}{l}\text { Accountancy, banking jobs, finance } \\
\text { jobs, and management }\end{array}$ & $0.051(0.024)^{* *}$ & $\begin{array}{l}0.070 \\
(0.020)^{* * *}\end{array}$ & $0.049(0.024)^{* *}$ & $0.065(0.028)^{* *}$ \\
\hline $\begin{array}{l}\text { Accountancy, banking jobs, finance } \\
\text { jobs, and management x Sexual } \\
\text { orientation }\end{array}$ & $-0.027(0.010)^{* *}$ & $-0.016(0.009)$ & $-0.023(0.010)^{* *}$ & $-0.010(0.006)$ \\
\hline $\begin{array}{l}\text { Social care, social services and charity } \\
\text { jobs }\end{array}$ & $0.017(0.010)$ & $0.004(0.005)$ & $0.018(0.014)$ & $0.004(0.005)$ \\
\hline $\begin{array}{l}\text { Social care, social services and charity } \\
\text { jobs x Sexual orientation }\end{array}$ & $-0.025(0.009)^{* *}$ & $-0.011(0.006)$ & $-0.028(0.009)^{* *}$ & $-0.014(0.008)$ \\
\hline Masculine personality traits & $0.037(0.045)$ & $0.094(0.073)$ & $-0.013(0.005)^{* *}$ & $0.081(0.069)$ \\
\hline $\begin{array}{l}\text { Masculine personality traits x Sexual } \\
\text { orientation }\end{array}$ & $-0.019(0.010)^{*}$ & $0.065(0.085)$ & $0.023(0.024)$ & $0.054(0.042)$ \\
\hline Feminine personality traits & $-0.014(0.008)$ & $0.058(0.046)$ & $0.024(0.010)^{* *}$ & $0.062(0.049)$ \\
\hline $\begin{array}{l}\text { Feminine personality traits } x \text { Sexual } \\
\text { orientation }\end{array}$ & $0.034(0.025)$ & $0.071(0.065)$ & $-0.015(0.008)^{*}$ & $0.142(0.107)$ \\
\hline Inexistence of equal opportunities & $0.045(0.038)$ & $0.053(0.064)$ & $0.052(0.043)$ & $0.058(0.052)$ \\
\hline $\begin{array}{l}\text { Inexistence of equal opportunities } \mathrm{x} \\
\text { Sexual orientation }\end{array}$ & $-0.011(0.005)^{* *}$ & $0.061(0.053)$ & $-0.012(0.006)^{* *}$ & $0.051(0.036)$ \\
\hline Controls & Yes & Yes & Yes & Yes \\
\hline Log Likelihood & -740.125 & - & -721.632 & - \\
\hline Prob $>$ Chi $^{2}$ & 0.000 & - & 0.000 & - \\
\hline $\mathrm{LR}_{\mathrm{Chi}}{ }^{2}$ & 84.148 & - & 84.438 & - \\
\hline Pseudo $\mathrm{R}^{2}$ & 0.051 & - & 0.043 & - \\
\hline Root MSE & - & 0.187 & - & 0.194 \\
\hline Prob $>F$ & - & 0.000 & - & 0.000 \\
\hline Adj $R^{2}$ & - & 0.654 & - & 0.736 \\
\hline $\mathrm{R}^{2}$ & - & 0.706 & - & 0.742 \\
\hline Observations & 5,628 & 3,469 & 5,470 & 3,445 \\
\hline
\end{tabular}

Notes: Panels I and II are linear probability estimations and we present average marginal effects. Panels III and IV offer OLS log estimations. The vector of controls accounts for: public sector jobs, fixed contract jobs, relocation package, London allowance, trade union, workplace size, workplace age, multinational firms, existence of human resources, online application, university entry standards, university Russell Group membership, regions, cover letter's type, curriculum vitae's type, and application's sending order. Robust standard errors are in parenthesis. ***Significant at the 0.001 level. **Significant at the 0.01 level. *Significant at the 0.05 level. 


\section{Appendix I. Cover Letter and Curriculum vitae}

\section{Cover Letter}

February/April 2013

Dear Sir/Madam,

Please find attached my Curriculum Vitae for your kind consideration for the vacancy as was advertised in... I am 21 years old and in July, I will be awarded a BSc [...] (2:1) from the University of ... I am very interested for the advertised job, and I would appreciate the opportunity to speak with you in person to further discuss my qualifications, your business objectives, and the talents I can bring to your organization. During my studies, I acquired strong academic skills, and I have ability to work in teams and to communicate well with others. The job you are offering matches both my personal and professional interests.

I look forward to hearing from you soon. In the meantime, please do not hesitate to contact me if you require further information.

Yours sincerely,

Name and surname

\section{Curriculum Vitae}

First Name:

Last Name:

Sex:

Ethnicity: White-British

Marital Status: Unmarried

Date of Birth: .../.../1991

Current Address: Location (university's city)

Telephone: Mobile

E-mail: University e-mail

Higher education

Level and subject of degree: BSc in [...], University of ...

Grade obtained: $61 \%$ (2:1)

Main courses of study: [...]

Duration of studies: 2009-2012 (3 year program)

High school education (State Schools; non fee-paying)

Names and addresses

Period of study and UCAS tariff score

Knowledge of SPSS [...]

Pre-professional experience

Practical experiences gained by delivering projects as a part of major modules [...].

Skills: Ability to work in teams and to communicate well with others.

I have gained organizational/financial skills by administrating my university's (gay and lesbian/human rights) union. I was responsible for the budget, and I had also fundraising responsibilities.

Personal characteristics: Likeable and friendly

Spare time interests: Cinema, music

Academic referees (contact details for two professors were provided) 


\begin{tabular}{|c|c|}
\hline Name & Definition \\
\hline Invitations for interviews & 1 if the applicant receives an invitation for interview; 0 otherwise \\
\hline Entry-level annual salary & Entry-level annual salary before taxes \\
\hline Gay men/lesbians & 1 if the applicant is labeled as being gay male/lesbian, $=0$ if not \\
\hline UCAS tariff system & University entry standards (per discipline) \\
\hline Russell Group member & 1 if a university is Russell Group member; 0 otherwise \\
\hline Male & 1 if the applicant is male; 0 otherwise \\
\hline Age & Years of age \\
\hline British-White & 1 if the applicant is British-White; 0 otherwise \\
\hline Married & 1 if the applicant is married; 0 otherwise \\
\hline Expected grade obtained & Expected grade obtained \\
\hline Working experience & Months of working experience \\
\hline Skills: Ability to work in teams & $\begin{array}{l}1 \text { if the applicant includes 'ability to work in teams' in her/his CV; } 0 \\
\text { otherwise }\end{array}$ \\
\hline Skills: Communication skills & 1 if the applicant includes 'communication skills' in her/his CV; 0 otherwise \\
\hline Personality: Likeable & 1 if the applicant includes 'likeable’ in her/his CV; 0 otherwise \\
\hline Personality: Friendly & 1 if the applicant includes 'friendly’ in her/his CV; 0 otherwise \\
\hline Spare time interest: Cinema & 1 if the applicant includes 'cinema as a hobby' in her/his CV; 0 otherwise \\
\hline Spare time interest: Music & 1 if the applicant includes 'music as a hobby’ in her/his CV; 0 otherwise \\
\hline Letters of references & $\begin{array}{l}1 \text { if the applicant provides contact details of at least } 2 \text { professors; } 0 \\
\text { otherwise }\end{array}$ \\
\hline Applicant location (city) & Applicant location (city) is university region (city) \\
\hline $\begin{array}{l}\text { Accountancy, banking jobs, finance jobs, and } \\
\text { management }\end{array}$ & $\begin{array}{l}1 \text { if the job opening is for accountancy, banking jobs, finance jobs, and } \\
\text { management (male-dominated jobs); } 0 \text { otherwise }\end{array}$ \\
\hline Education and teaching jobs & $\begin{array}{l}1 \text { if the job opening is for education and teaching jobs (female-dominated } \\
\text { jobs); } 0 \text { otherwise (excluded category in the regression stage) }\end{array}$ \\
\hline Social care and charity jobs & $\begin{array}{l}1 \text { if the job opening is for social care, social services and charity jobs } \\
\text { (female-dominated jobs); } 0 \text { otherwise }\end{array}$ \\
\hline Fixed contract & 1 if the vacancy is on a fixed term contract; 0 otherwise \\
\hline Relocation package & 1 if the firm offers relocation package; 0 otherwise \\
\hline London Allowance & 1 if the firm offers London allowance; 0 otherwise \\
\hline Workplace age & 1 if the firm is established more than 20 years; 0 otherwise \\
\hline Workplace size & 1 if the firm employs more than 200 people; 0 otherwise \\
\hline Multinational firm & 1 if the firm is multinational; 0 otherwise \\
\hline Human resources & 1 if there exists human resource department; 0 otherwise \\
\hline Equal opportunities & 1 if the firm has a formal written equal opportunity policy ; 0 otherwise \\
\hline Trade union & 1 if there exists employees' trade union; 0 otherwise \\
\hline Online application & 1 if the applicants had to fill in an online application form; 0 otherwise \\
\hline Firm region (city) & Firm region is applicant location (city) \\
\hline Advertised masculine personality traits & $\begin{array}{l}1 \text { if the job opening describes the ideal job applicant as ambitious, acts as a } \\
\text { leader, assertive, dominant; } 0 \text { otherwise }\end{array}$ \\
\hline Advertised feminine personality traits & $\begin{array}{l}1 \text { if the job opening describes the ideal job applicant as affectionate, } \\
\text { cheerful, gentle, sensitive to the needs of others; } 0 \text { otherwise }\end{array}$ \\
\hline East Midlands & 1 if the applicant applied for a vacancy in East Midlands, 0 otherwise \\
\hline East of England & 1 if the applicant applied for a vacancy in East of England, 0 otherwise \\
\hline London & $\begin{array}{l}1 \text { if the applicant applied for a vacancy in London, } 0 \text { otherwise (excluded } \\
\text { category in the regression stage) }\end{array}$ \\
\hline North East & 1 if the applicant applied for a vacancy in North East, 0 otherwise \\
\hline North West & 1 if the applicant applied for a vacancy in North West, 0 otherwise \\
\hline Northern Ireland & 1 if the applicant applied for a vacancy in Northern Ireland, 0 otherwise \\
\hline Scotland & 1 if the applicant applied for a vacancy in Scotland, 0 otherwise \\
\hline South East & 1 if the applicant applied for a vacancy in South East, 0 otherwise \\
\hline South West & 1 if the applicant applied for a vacancy in South West, 0 otherwise \\
\hline Wales & 1 if the applicant applied for a vacancy in Wales, 0 otherwise \\
\hline West Midlands & 1 if the applicant applied for a vacancy in West Midlands, 0 otherwise \\
\hline Yorkshire and the Humber & $\begin{array}{l}1 \text { if the applicant applied for a vacancy in Yorkshire and the Humber, } 0 \\
\text { otherwise }\end{array}$ \\
\hline
\end{tabular}

